\title{
KELTI - KLASICKÁ A MODERNÁ PARADIGMA
}

\author{
Peter Šalkovský
}

DOI: https://doi.org/10.31577/szausav.2019.suppl.1.28

Keywords: the Celts, classical and modern paradigm, ethnicity, Celtic languages, archaeology, linguistics

\section{The Celts - classical and modern paradigm}

The article deals with two paradigms (models) in the research of the big group of tribes called Keltoi, Celtae, Galoi by antique authors; the tribes lived in a large part of Central, Western and Southern Europe and Asia Minor in the $6^{\text {th }}$ century $\mathrm{BC}$ to the $2^{\text {nd }}$ century $\mathrm{AD}$ or as late as the Middle Ages and, in fragments, they live until now in part of France and on the British Isles.

In the last few decades, scientific research, mainly in archaeology, has moved from traditional interpretations of the Celts as one big ethnic group (or a large group of linguistically and culturally related Celtic tribes) growing into a kind of Celto-mania with part of mainly lay public, to doubts about Celtic ethnicity or even its denial and sceptical attitude towards its identifiication with the archaeological La Tène culture. Attempts to interprete migration and historical fate of individual Celtic tribes, with the exceptions documented by contemporary written sources, have been viewed with scepticism or abandoned. This situation can be solved by a combination of research results from several scientific disciplines, mainly linguistics (research of use of personal nouns and other Celtic words on archaeological or iconographical artifacts and geographical names), history, archaeology, genetics and party biochemistry, geochemistry and molecular medicine. This could bring further progress in the study of the Celts.

Paradigma (z gr. parádeigma = vzor, príklad, model) je všeobecne prijímaná schéma, vzorec či model myslenia. $\mathrm{V}$ humanitných a spoločenských vedách je tvorená súhrnom základných prístupov vedy k svetu, súborom predstáv a predpokladov danej skupiny vedcov, platforma, na ktorej je predmet výskumu vnímaný. Mení sa na základe principiálne nových vedeckých poznatkov.

„Keltmi“ (Keltoi, Celtae, Galoi) nazývali antickí grécki a rímski autori vel'kú skupinu kmeňov obývajúcich pôvodne strednú a západnú Európu severne od Álp, ked’ začali prenikat južnejšie a dostali sa tak do styku s antickým svetom. ${ }^{2}$ Germáni ich označovali variáciami slova "Walhaz, Welsch, Walhisk, Waals“, čo znamená ",cudzinec“, „románsky alebo keltský hovorca“, a používali ho na pomenovanie obyvatelov bývalej Západorímskej ríše, ktorí boli už po zlome letopočtu do značnej miery romanizovaní a hovorili latinsky alebo keltskými jazykmi. Počas niekol'kých storočí však skoro všetky tieto komunity splynuli s helenistickou a provinciálnou rímskou kultúrou. Iba na okraji impéria v Bretónsku, Británii a za jeho hranicami v Írsku žila keltská kultúra a jazyk d’alej, a tak je to, hoci v značne menšej miere, iba zlomkovite dodnes. ${ }^{3}$

V stredoveku povedomie o keltskej minulosti prakticky zaniklo. To sa zmenilo až za humanizmu s návratom k antickým literatúram. Neskôr v 18. stor. sa zrodilo to, čo dodnes poznáme ako moderný pojem Kelti. Začalo sa intenzívne archeologické, historické i jazykovedné bádanie o Keltoch produkujúce početnú keltologickú literatúru, na základe ktorej sa v minulom storočí dotvorila klasická paradigma o Keltoch, ich spoločnosti a kultúre, popularizácia, ktorej vyústila miestami až do tzv. keltománie.

Ako sa ešte dnes vyučuje (a to nielen školách nižšieho stupňa), a to majú vo svojej pamäti uložené i mnohé generácie nielen európskych archeológov a historikov, Kelti mali mat’ svoje počiatky v osídlení severných Álp, hornodunajských regiónov, vrátane Bavorska, južných a západných Čiech, archeologicky označovaného ako západohalštatský okruh. Vznikla a existovala tu tzv. laténska materiálna kultúra

\footnotetext{
Príspevok bol vypracovaný v rámci projektu APVV-16-0449 „Stredoveká Nitra v hmotných prameňoch“.

Asi prvý bol Herodotos, ktorý v 5. stor. pred n. l. píše o národe „Keltoi“ na území strednej Európy v krajine „Keltika“.

3 Vo Vel'kej Británii a Írsku sa keltské jazyky a kultúra znovu obrodzujú a oživujú (dokonca jazyky pokladané už za mŕtve ako cornština či mančina) v rámci existujúcej vyspelej demokracie, z iniciatívy jednotlivcov, občianskych združení i za podpory štátu (Kokaisl a i. 2016).
} 
indikujúca príbuzný spôsob života, hospodárstvo, kult i organizáciu spoločnosti. Z tohto územia sa už od 6., a hlavne v 5.-3. stor. pred n. 1. šírili kultúrne vplyvy a následne v niekol'kých vlnách expanzie aj samotní nositelia tejto kultúry - Kelti, viacerými smermi (obr. 1). Na prelome 5. a 4. stor. pred n. l. antickí autori zaznamenali mená viacerých keltských kmeňov, ktoré sa dostali do priameho kontaktu s južným svetom a postupovali do Stredomoria, Grécka a Itálie, kde na rôznych miestach získavali nové územia. V rovnakom období prichádzali Kelti aj do stredného Podunajska a Karpatskej kotliny. Ich osídlovanie, podla mapovania nálezov jednotlivých druhov typických artefaktov, prebiehalo vo viacerých vlnách a z rôznych oblastí západnej Európy.

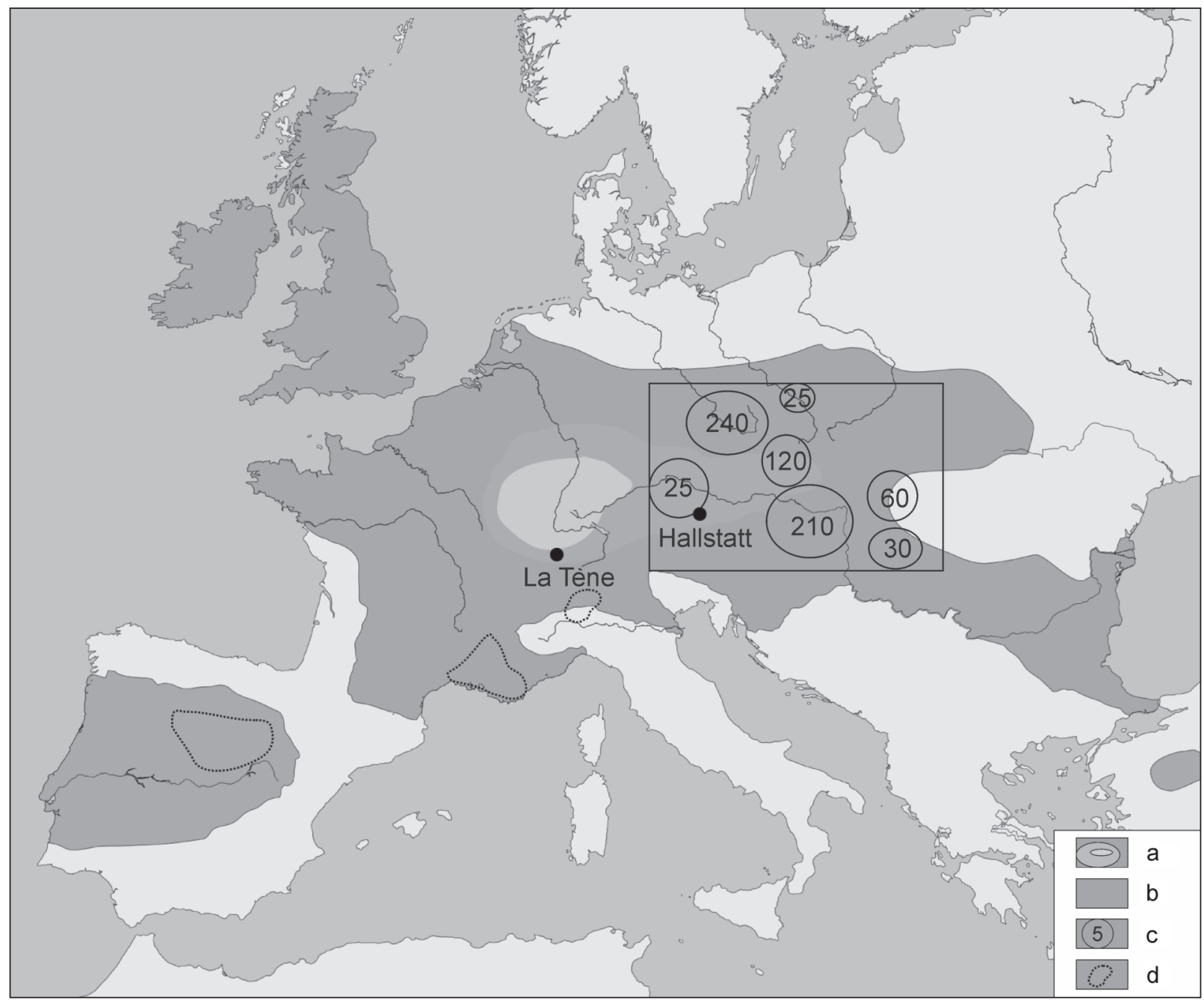

Obr. 1. a - pravlast' Keltov; b - rozšírenie Keltov v 5.-1. stor. pred n. 1. podla klasických interpretácií; c - rozšírenie keltských plochých pohrebísk v strednej Európe (hlavné makroregióny s približnými počtami pohrebísk); d - schematické vyznačenie oblastí výskytu najstarších včasnokeltských nápisov (podla Birkhan 1997, obr. 32, upravené; Filip 1995, obr. 19). Mapový podklad: https://commons.wikimedia.org/wiki/File:Celts.svg [01. 03. 2018].

V 3. a 2. stor. pred n. 1. boli už Kelti zo svojho pôvodného územia rozšírení všetkými smermi (od Atlantického oceána až po/za/ Karpatskú kotlinu, dolné Podunajsko, Balkán a Malú Áziu). Dlhodobo priaznivý politický i hospodársky vývoj keltských spoločenstiev vyvrcholil v dobe protourbánnych keltských oppíd a obrovských polyfunkčných nížinných sídlisk.

V 1. stor. pred n. l. sa dostali viaceré keltské kmene medzi Malou Áziou, Alpami a Atlantikom, včítane častí Pyrenejského polostrova a Británie, pod rímsku nadvládu a ich územia na sever od Dunaja postupne obsadzovali Germáni. Na podhorských územiach stredného a severného Slovenska žil ešte v 1. a 2. stor. n. l. v susedstve germánskych Kvádov pravdepodobne keltský kmeň Kotínov. Celkovo boli zvyšky latén- 
skej civilizácie východne od Rýna a severne od Dunaja, teda mimo rímskej jurisdikcie, postupne úplne prekryté germánskou, vo svojej podstate hlboko pravekou kultúrou.

To je iba velmi stručný pohlad na dejiny keltských kmeňov v rámci „starej“ klasickej paradigmy (napr. Birkhan 1997; 2009; Ćižmářová 2004; Drda/Rybová 1998; Filip 1995; King 1999; Koch/Minard 2012; Pieta 2008; Waldhauser 2006; 2012, s literatúrou).

$\mathrm{V}$ posledných desałročiach prebiehali kritické polemiky $\mathrm{k}$ výpovedným možnostiam archeológie v oblasti etnicity všeobecne a v súvislosti s tým nastáva postupne aj prechod od keltománie ku keltoskepticizmu (Sims-Williams 1998; 2012a; 2012b). Dnes teda máme značné problémy aj s etnicitou Keltov, resp. etnicitou vel'kej skupiny kmeňov, hlavných nositelov laténskej kultúry, hoci tu disponujeme aj pomerne početnými historickými, jazykovednými, epigrafickými, paleografickými, ikonografickými i inými prameňmi. Aj medzi poprednými európskymi odborníkmi, keltológmi, resp. archeológmi zaoberajúcimi sa dobou laténskou, zavládli po desatročiach bádania, interpretácie a publikovania „keltských" sídlisk, pohrebísk či oppíd pochybnosti až skepsa. Viacerí si začínajú osvojovat iný pohlad na „etnickú identitu a etnogenézu Keltov “. ${ }^{4}$ Prezentovaný je dnes v rámci novej paradigmy, opierajúcej sa o výskumy a hypotézy v oblasti vznikania a premien etnických identít a (ne)možností archeológie či presnejšie obmedzených možností výpovede materiálnej kultúry o etnickej identite jej nositelov, teda jednotlivých dávnych komunít, archeologických kultúr a historicky známych kmeňov.

Podla novej paradigmy Kelti ako etnikum vlastne neexistovali, pretože historicky pod vlastnými menami sú doložené iba jednotlivé kmene, ktoré nemali spoločnú etnickú identitu (teda sami sa neoznačovali za Keltov) a iba vonkajší pozorovatelia ich označovali strešným názvom Kelti. Laténska kultúra, ktorá znamenala zhruba v posledných piatich storočiach pred zlomom letopočtu značné kultúrne zjednotenie podstatnej časti Európy severne od Álp, a bola považovaná za typický archeologický prejav Keltov, sa interpretuje ako polykultúrny civilizačný prejav. Na jej vzniku sa jednotlivé „keltské“" kmene iba spolupodielali, i ked’ pravdepodobne mali hlavný, profilujúci podiel. Bazálnym problémom je, že archeológia pracuje iba so zlomkami zachovanej materiálnej kultúry, ku ktorej väčšinou úplne chýbajú nemateriálne zložky kultúry. Je nepochybné, že i materiálna kultúra je schopná do istej miery odrážat etnicitu, no jej vznik a zmeny sa dávajú do súvislosti prevažne so zmenami v sfére hospodárskej, sociálnej a politickej, alebo ich možno interpretovat aj ako reakcie na zmenené prírodné a životné podmienky. Aj tie prvky, ktoré v zásade môžu byt' nositel'mi informácie o etnicite, môžu byt’ a sú často interpretovatelné aj inak ako vojnová korist', predmet obchodu, výmeny či dar, alebo naznačujú možnost̉ interakcií a vzájomných kontaktov rôzneho druhu medzi jednotlivými kultúrami (Müller 2009, 96; Schreiber 2008, 62).

Pripúšta sa, že jednotlivé vybrané znaky z daného celku archeologických nálezov môžu naznačovat vyjadrenie skupinovej príslušnosti, ale tie sa vo väčšine prípadov nezhodujú alebo nemusia zhodovał $\mathrm{s}$ tzv. etnickými signálmi, ktoré by mohli prispiet k objasneniu etnickej príslušnosti svojich nositelov (Sommer 2003, 212). Zdá sa, že na základe analýzy archeologického materiálu nemožno jednoznačne určit etnickú príslušnost̉ jedincov či skupín obyvatelstva. Možno však objasnił existujúce priestorové štruktúry (Müller 2009, 105), teda vymedził jednotlivé archeologické kultúry a ich súčasti. Tieto priestorové štruktúry však poskytovali priestor pre komunikáciu a práve preto existujú predpoklady, že sa v nich mohol vyvinút určitý druh kolektívnej identity, najčastejšie kmeňové spoločenstvo. ${ }^{5}$ Komunikácia, bez ktorej túto kolektívnu identitu nebolo možné dosiahnut', si vyžadovala spoločný dorozumievací prostriedok. Existenciu vzájomne zrozumitelného jazyka máme v písomnej podobe doloženú už u niektorých vyspelých neolitických kultúr. Aj ked’ je z histórie i súčasnosti známe, že tento atribút, spoločný jazyk pre vznik a vymedzenie etnickej skupiny, nie je úplne nevyhnutný, a dokonca sa časom môže podstatne zmenit či nahradit iným jazykom, ${ }^{6}$ je predsa len jedným z činitelov významne sa podielajúcim na progrese organizácie komunít a ich etnogenéze.

Ak by sme uznali za jediné správne a vedecké tvrdenia, že etnicitu jedincov či skupín možno spolahlivo určit iba na základe priameho svedectva skúmaných jedincov a skupín (napr. Davidovic 2008, 13), resp. pripustit skepticky, že všetky archeologické nálezy nezmienené priamo v písomných zdrojoch

\footnotetext{
Napr. Goudineau/Guichard/Kaenel 2010; Salač 2011; http://www.ceskatelevize.cz/ct24/archiv/1132884-keltove.

5 Príslušníci jedného kmeňa zvyčajne zdiel’ali jazyk, náboženské rituály, jednotný systém hierarchie a autorít. Žiadny z týchto atribútov však nie je úplne nevyhnutný. Bazálnym predpokladom vzniku kmeňa je potreba koordinácie del'by práce a spotreby hodnôt, produktov v danom spoločenstve (Fried 1975).

6 V Írsku írčina patrí medzi keltské jazyky. Je národným a prvým úradným jazykom štátu, napriek tomu väčšina obyvatelstva i úrady používajú hlavne angličtinu. Bosniaci alebo Bosňania sú v súčasnosti tvorení troma entitami, národmi: Bosniakmi (bosnianski moslimovia), Srbmi a Chorvátmi; Kurdi rozprávajú tromi značne odlišnými dialektami, atd’.
} 
zostávajú bezmenné, a teda etnicky nedefinovatelné (Schreiber 2008, 16, 17), naozaj môžeme na bádanie v oblasti etnicity nielen pravekých, ale akýchkolvek nežijúcich jedincov, okrem tých, ktorých etnicita bola nejakým spôsobom dôveryhodne zaznamenaná, zabudnút. A mali by sme následne odstránił z odbornej literatúry všetky „etnické" názvy a termíny vo vzt̉ahu k materiálnej kultúre, sídliskám, pohrebiskám, kmeňom či iným predštátnym i štátnym útvarom. Teda nepoužívat termíny ako keltské, germánske, slovanské, staromad’arské, longobardské či kvádske, ale často ani franské, saské, anglické sídlisko, pohrebisko, osídlenie, či dokonca keltský meč, kopija, germánsky sax, spona, keramika atd’.

Napriek spomenutým, v súčasnosti prevažujúcim skeptickým názorom nemožno pokusy $\mathrm{v}$ tomto smere explicitne vylúčit. Pre archeológiu je v tejto oblasti nevyhnutná spolupráca najmä s lingvistikou. Obzvlášt jazykové certifikáty a kvalifikované lingvistické štúdie môžu mat mimoriadny význam pri formulovaní výrokov o historických etnických komunitách.

Je pravdou, že Kelti, podobne ako väčšina známych vel'kých kmeňových aj etnických skupín, boli pomenovaní zvonku. Inak celý okolitý svet nazýval „Keltov“ jednotlivými kmeňovými menami, ktorými sa i sami nazývali. Z nich nie sú bližšie známe a lokalizované zd’aleka všetky. Vieme s istou pravdepodobnostou, že v juhovýchodnom Mad’arsku a Vojvodine žili Skordiskovia, na územiach dnešného Bavorska Vindelikovia, pri Bójoch sa uvažuje o ich sídlení v Čechách či neskôr na juhozápade Slovenska. Omnoho viac názvov keltských kmeňov sa zachovalo v západnej Európe (napr. Arvernovia, Eburonovia, Haeduovia, Sekvani, Volkovia, Senoni či Parisiovia na území dnešného Francúzska, Belgovia dali meno dnešnému Belgicku, kde žili ešte Ambiáni, Bellovakovia, Suessióni a Nervi; na Britských ostrovoch to boli Brigantovia, Catuvellauni, Atrebati, Corieltauovia, Deceanglovia, Dobunovia, Durotrigovia, Regniovia, Piktovia, Trinovantiovia a další). V Malej Ázii sa usadili Trokmiovia, Tektoságovia a Tolistobogiovia (napr. Filip 1995; Maier 2000; 2015; Zimmer 2017).

$\mathrm{V}$ súčasnosti prevažujú koncepcie kmeňov ako dynamických vznikajúcich (ale časom často i zanikajúcich) kolektívnych identít, ktoré viac ako pokrvná blízkost' zjednocovala spoločná „kultúra“, t. j. spôsob života, hospodárenia, sídlenia, bývania, módy, spoločné záujmy $\mathrm{v}$ obrane a presadzovaní svojich záujmov v opozícii $\mathrm{k}$ okolitému svetu, upevňované spoločným kultom, obradmi a kolektívnou pamätou. Skúsenostami a v spoločných rituáloch s inými rodmi si ludia osvojovali modul príbuznosti, rozširovali spoločné skúsenosti, názory na svet a povedomie spoločnej tradície. Takto vznikli

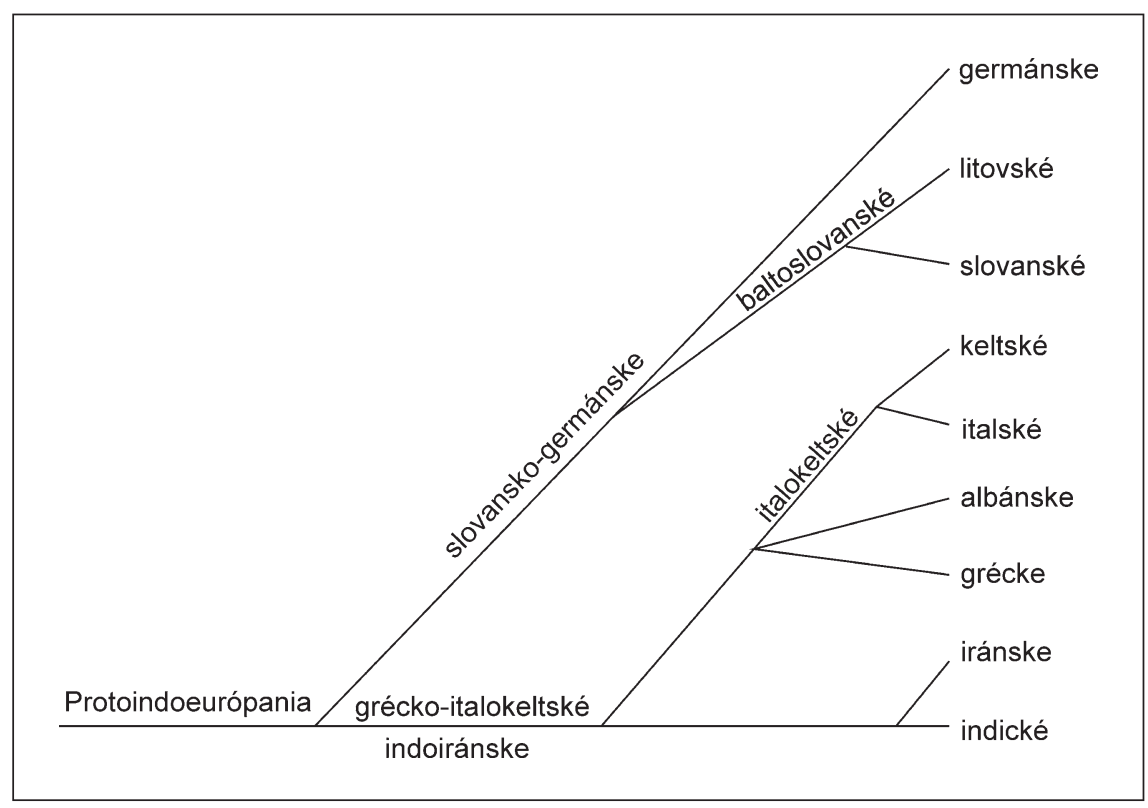

Obr. 2. Keltské jazyky v rámci rodokmeňa indoeurópskych jazykov (Lehman 1992, 120; Stifter 2008, obr. III. 1. 1, upravené).

mytológie rozvíjajúce a udržiavajúce tradíciu príbuznosti a zdielanej kolektívnej identity (Wenskus 1961). Viaceré súčasti jednotky kmeňa pritom mohli byt̉ často rôzneho pôvodu, ako to máme doložené z neskorších dôb písomnými prameňmi, napr. medzi Longobardov v 2. pol. 6.-8. stor. v Taliansku boli začlenené menšie či väčšie skupiny Gepidov, Svébov, Alamanov, Sasov, zvyšky Ostrogótov, Alzekových Bulharov, Rimananov a iných (Pohl 1991, 41).

Etnické skupiny teda boli i sú dynamickými jednotkami, ktoré sa menia ako v čase, tak v priestore, rovnako ako sa menia hranice medzi jednotlivými etnickými skupinami a stupňom intenzity vnímania vlastnej etnickej identity (Jones 2003). Jednotlivé archeologické kultúry sa nezhodujú, resp. nemusia sa presne zhodovat’ s jednotlivými etnikami, okrem iného i preto, že každá konkrétna archeologická 
kultúra (jej obsahová i časopriestorová definícia ${ }^{7}$ ) je konštrukt vytvorený s cielom archeologickej klasifikácie a rekonštrukcie, konštrukt, ktorý nemožno stotožnit s inými klasifikačnými jednotkami lingvistickými, sociologickými alebo etnickými (Collis 1997, 173; 2003).

Je známe, že keltské kmene všeobecne nepreukazovali nejakú mimoriadnu vnútornú jednotu, pocit spolupatričnosti. Popri spojenectvách existovali aj početné vnútrokeltské nezhody a kmeňové vojny časté taktiež u iných kmeňov. Napriek tomu vieme, že si uvedomovali príbuznú identitu. Svedčí o tom fakt, že všetky hovorili vzájomne zrozumitelnými „keltskými“ dialektmi, resp. jazykmi vychádzajúcimi zo spoločného protojazyka a zdielali vel’mi blízku mytológiu, z ktorej vychádzali aj starobylé keltské literárne pamiatky (Vlčková 2002).

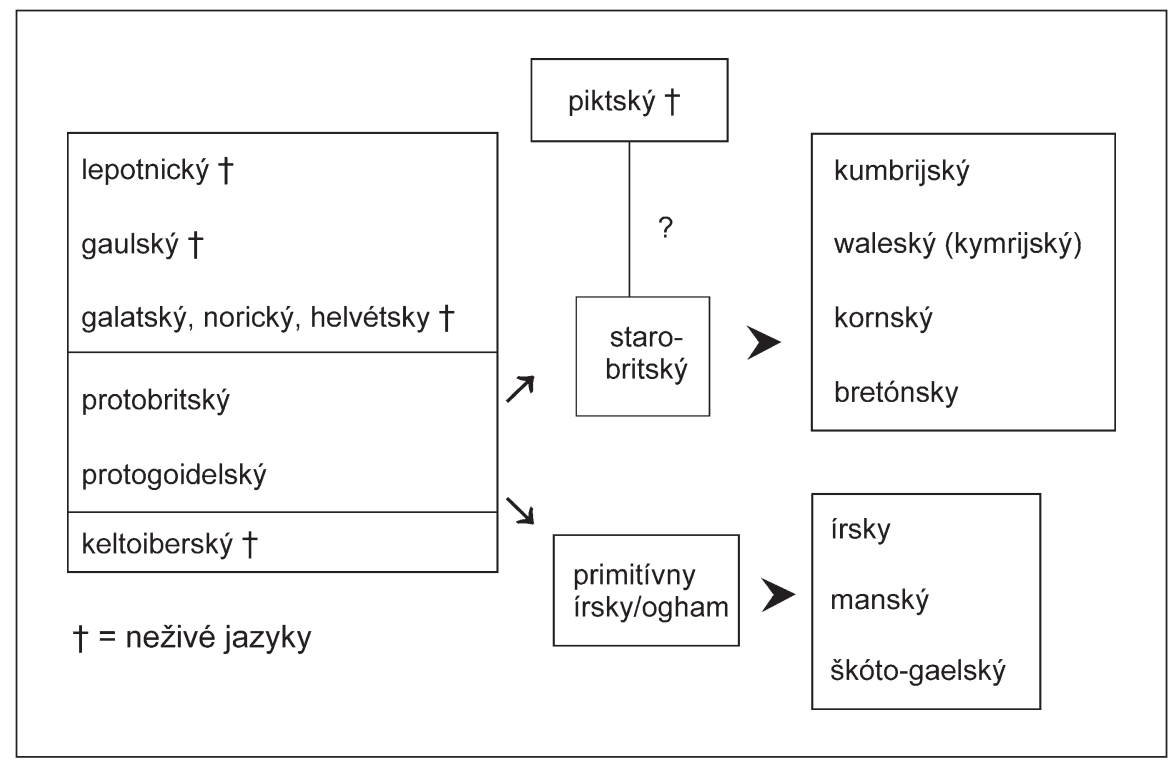

Obr. 3. Genealógia keltských jazykov (Stifter 2008, obr. III. 1. 4 - upravené).

Môžeme asi predpokladat', že neexistovala nejaká pôvodná jednotná keltská etnicita, podobne tak germánska, baltská, turkická či slovanská, aj ked' nepochybne všetky tieto vel'ké etnické jazykové skupiny mali v globále príbuzný pôvod a prajazyk. Pracovne by sa možno dali nazvat' protoetnikami, bazálnymi jazykovo-kultúrnymi vetvami vel'kej jazykovej rodiny, $\mathrm{v}$ tomto prípade praindoeuprópskej (obr. 2). Takýchto fylogenetických skupín (jazykových rodín) celosvetovo lingvistika definovala viac než 40 a okrem nich takmer dvojnásobný počet tzv. neklasifikovaných a izolovaných jazykov. ${ }^{8}$ Historický vývoj jazykových rodín, včítane indoeurópskej, smeroval k oddelovaniu skupín, ich fragmentáciám a vznikaniu samostatných jazykov. Z ich nositelov, jednotlivých kmeňov a etník, sa iba menšine podarilo udržat kolektívne etnické povedomie a cez rôzne stredoveké mocenské útvary sa vyvinút do samostatných novodobých moderných národov. Keltské jazyky sa najprv oddelili do vetvy grécko-italokeltskej, tá sa vyvíjala do dvoch vetiev grécko-albánskej a italokeltskej, aby v d’alších storočiach došlo k osamostatneniu keltčiny a k jej rozčleneniu postupne až na 17 dnes už väčšinou nežijúcich starých keltských jazykov (obr. 3; Lehman 1992, 65-90; Stifter 2008, obr. III. 1. 1).

Najstaršie doklady keltčiny, datované do 6. stor. pred n. 1., nepoznáme z predpokladaných miest najstaršej keltskej etnogenézy severne od Álp, ale z oblasti kultúry Golasecca v severnom Taliansku a južnom Švajčiarsku, a to z jej vetvy nazvanej lepontická. Poznáme odtial' okolo 140 nápisov na kamenných článkoch a minciach, najmä osobných a miestnych mien, čo dokladá, že tam žili keltskí hovorcovia, tzv. Lepontiáni, kultúrne a jazykovo úzko súvisiaci s neskoršími Keltmi severného Talianska (Galli cisalpini; Maier 2015; Stifter 2008, obr. III. 1. 4). Súvisí to zrejme s tým, že znalosṫ najstaršieho písma prišla ku Keltom z juhu od Etruskov a z centrálnych rímskych území v Toskánsku. Ďalšie väčšie koncentrácie včasných nápisov v niektorom $\mathrm{z}$ keltských jazykov evidujeme na galohelénskom území v okolí Marseille, u Keltoiberov na Pyrenejskom polostrove, v Dácii i Malej Skýtii, neskôr i na Britských ostrovoch a zväčša mladšie nápisy na kamenných artefaktoch a minciach v rôznych častiach keltského sveta včítane územia Slovenska.

\footnotetext{
Časovo a priestorovo ohraničený súbor lokalít a artefaktov vyznačujúcich sa zhodnou povahou hmotného (a v ňom sa odrážajúceho duchovného) prejavu: typmi, tvarmi a výzdobou artefaktov, použitými výrobnými technológiami, spôsobom zakladania osád a budovania obydlí, spôsobom pochovávania mŕtvych atd'.

https://sk.wikipedia.org/wiki/Jazykov\%C3\%A1_rodina.
} 
Keltské jazyky sú pomerne dobre preskúmané. Na pevninskej Európe existovali vetvy, a to lepontická, doložená už zo 6. stor. pred n. 1., galská, s prvými dokladmi z 5. stor. pred n. 1., keltoberiská z 3. stor. pred n. l. Mladšie ostrovné keltské jazyky sú delené na goidelské alebo tiež gaelské, ktoré sa rozvinuli do írskeho, škótskeho a manského jazyka a britské, ktoré tvorili predchodcov kymrijského (waleského ${ }^{9}$ ), cornwallského, bretónskeho a kumbriánskeho jazyka (obr. 3; Kokaisl a i. 2016, 22; Stifter 2008, obr. III. 1. 1). Jedinci a skupiny hovoriace živými keltskými jazykmi sa pokladajú vo väčšine prípadov za potomkov Keltov a dedičov ich kultúry, bez ohladu na svoju antropologickú, genetickú či genealogickú bázu, úplne oprávnene (a to aj z pohladu vied zaoberajúcich sa kriticky etnickou identitou).

Je zaujímavé, že etnicita jednotlivých „keltských kmeňov“ je spochybňovaná argumentáciou, že ich antickí autori označovali kmeňovými menami, kedže ani obyvatelov Škandinávie neoznačoval antickí autori za Germánov. Napriek tomu nikto nespochybňuje, že by Island’ania, Nóri, Švédi a Dáni neboli z jazykového a kultúrnohistorického hladiska jednoznačne Germáni. V prípade Keltov sa s tým spája ešte d’alší závažný argument, na ktorý kritici ideológie etnicity radi zabúdajú, a tým je, že v Írsku kultúrna kontinuita z doby laténskej a rímskej dodnes trvá nielen jazykovo a literárne, ale existuje aj materiálna kontinuita írskej kultúry. Zodpovedá onej starokeltskej kultúre, ako ju opisujú antickí autori a odráža sa v samotnej írskej literatúre. Na rozdiel od Británie nebolo Írsko nikdy dobyté Rímskou ríšou a zatial čo po páde Ríma na mnohých územiach bývalej ríše dochádzalo k chaosu, na území Írska, naopak, prekvitala predliterárna keltská tradícia, z ktorej neskôr čerpala írska literatúra. Historická lingvistika úplne nezávisle na archeologických svedectvách a rýdzo formálnymi prostriedkami preukázala úzku spriaznenosṫ jazykov ako starovekých pevninských, tak stredovekých ostrovných Keltov. Upierat spomínaným lud’om a jazykom právo patrit medzi „,keltské“ je preto nezmysel. Tam, kde sa podobné snahy prejavujú, možno vystupujú na povrch hlboko uložené emócie (pocity vyvolávajúce obranu či agresiu) alebo aj politicky motivované ideológie (šovinizmus, imperializmus, rasizmus), ktoré zodpovedajú skôr duchu 19. než 21. storočia (Zimmer 2017).

Vel'ké územia osídlené viacerými keltskými kmeňmi, začlenené postupne do Rímskej ríše, niesli ich celoetnické mená - rímske provincie vel'ká Galia, menšie Galia Narbonencis, Galia Lugdunensis, Galia Transalpina či Cisalpina a v Malej Ázii „„štát“ Galatov, Galatia. Podobne pri názvoch území osídlených germánskymi kmeňmi severnejšie užili Rimania „zjednocujúci“ názov ako Germania Magna, Germania Superior či Inferior. Ich blízka etnická identita bola teda uznaná aj zvonku.

Pokial ide o maloázijskú Galatiu (existujúcu približne dva a pol storočia - 278-24 pred n. 1.), historická a etnická identita galatských/keltských kmeňov (Trokmiov, Tektoságov a Tolistobogiov) boli definované nielen Galatmi samotnými, ale boli im tiež priznané inými etnikami. V rámci územno-organizačnej štruktúry Galatie sa zachovala tradícia a identita Galatov i počas rímskych čias (Strobel 2009). Hlavou Galatie, rovnako ako celého impéria sa vtedy stal cisár, význačnú pozíciu však stále mal predstavený tzv. galatského spoločenstva, galatarchés. Galatská aristokratická vrstva bola po začlenení Galatie do rímskeho impéria integrovaná do nových spoločenských štruktúr a stala sa reprezentantom lojality voči rímskym vládcom, čo jej nespôsobovalo žiadne problémy. Jej členovia dostali dokonca rímske občianstvo, ale napriek formálnej príslušnosti k rímskemu impériu i k helenistickému svetu v nich pretrvávalo určité povedomie a hrdost̉ vo vzt̉ahu $\mathrm{k}$ ich galatskému pôvodu. Je však zaujímavé, že laténska kultúra sa v rámci Malej Ázie v súvislosti s prítomnostou keltských kmeňov nevytvorila a nedošlo ani k vytvoreniu miestnej odnože kultúry lokálneho pôvodu, na ktorej by bol zjavný vývojový proces. Prítomnost̉ a aktivity keltských kmeňov sa dajú sledovat iba čiastočne, napr. na nálezoch stredolaténskych spôn, náramkov a kruhov. Iné druhy nálezov, napr. mince však nereprezentujú relikt laténskej európskej hmotnej kultúry v maloázijskom helenistickom prostredí, naopak sú dokladom pokročilej helenizácie maloázijských Keltov (Strobel 2006, 90; Trefný 2007, 75-105).

Podobne ako germánske kmene a ich barbarské královstvá neboli monoetnické ani keltské „královstvá" a kmene. Počas svojich pohybov po Európe absorbovali menšie či väčšie fragmenty iných príbuzných kmeňov, ale aj domorodého osídlenia (na severovýchode zrejme hlavne potomkov trácko-ilýrskeho pôvodu, na územiach Rímskej ríše zas helenizované či romanizované obyvatel'stvo, alebo v Hispánii Iberov). Pritom dochádzalo ku kultúrnym, politickým, náboženským i osobným interakciám a k preberaniu mnohých prvkov v hospodárstve, výrobe i správe. Nakoniec však nielen Galati, Keltoiberi, ale i d’alšie početné keltské komunity obklopené d’aleko početnejšími etnikami pod tlakom rímskej antickej civilizácie a následne Germánov podlahli asimilácii.

\footnotetext{
9 Názov kymrijčina je samopomenovanie hovorcov, waleština je podl’a názvu Welsh, ktorý dali anglosasskí osadníci keltským kmeňom.
} 


\section{ZÁVER}

Pri dalšom skúmaní etnickej identity protohistorických i stredovekých spoločenstiev, t. j. toho, čo možno nazvat' keltský, ilýrsky, skýtsky, ale i germánsky, gepidský, longobardský, hunský, slovanský, obodritský, pol'ský a podobne, je potrebné pokúsit sa definovat predmet, jav, štruktúru, čo sa tak dá pomenovat' historicky, jazykovo alebo archeologicky. Tieto individuálne definície nemôžu byt’ stotožňované, ale iba porovnávané, pretože sú to odlišné javy. Treba byt̉ kritickejší pri konotácách etnickej jednoty vo vztahu k akýmkolvek vel'kým sociálnym skupinám či identitám, nie iba ku Keltom, pretože ako také $\mathrm{v}$ jednom celku, $\mathrm{v}$ rovnorodej štruktúre a nejakej spoločnej organizácii pravdepodobne nikdy neexistovali. Napriek tomu sú isté zjednodušenia a generalizácie vždy nutné, aby daný jav, kultúru, bolo možné nejako uchopit’ a väčšinovo charakterizovat pre laickú, ale aj odbornú verejnost̉. Bezmenné dejiny asi nikoho zaujímat nebudú. Aj k opisu dejín predkov časti jazykov a národov dnešnej Vel'kej Británie a Írska potrebujeme nejaké kolektívne meno. Výraz Kelti má síce „chyby“, je zjednodušujúci,10 ale je to asi najlepšie, čo máme.

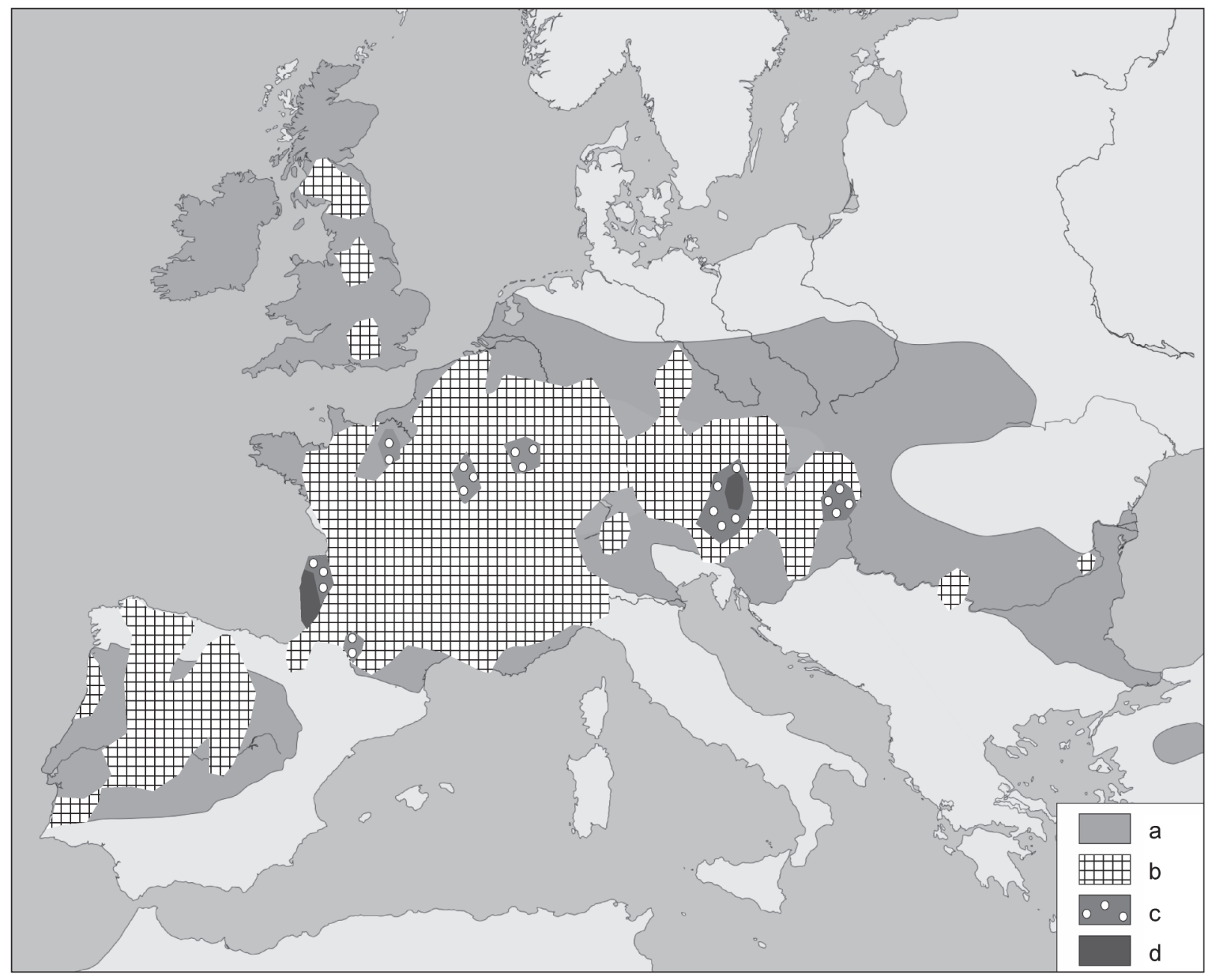

Obr. 4. Schematizované zobrazenie hustoty výskytu latinských nápisov v Rímskej ríši s keltskými menami (ako percentuálny podiel zo všetkých latinských nápisov). a - rozšírenie keltských kmeňov; b - nízky výskyt (asi 0,1-2,9 \%); c - stredne vysoký výskyt (asi 3-3,9 \%); d - najvyšší výskyt (asi 4-6 \%; podla Raybould/Sims-Williams 2007, upravené).

\footnotetext{
10 Podobných zjednodušní sa dopúštame aj dnes, ked hovoríme, že v Londýne žijú Angličania, v Paríži Francúzi, hoci v skutočnosti tam žije jazykovo i národnostne vel’mi pestrá mozaika. Väčšinovo sú to ale Angličania a Francúzi. A tí, ktorí sa nimi necítia dnes, sa možno budú cítit o pár rokov, resp. v druhej, tretej generácii.
} 
Etnická identita je druh sociálnej identity, ktorý skupina prijíma a neustále vymedzuje. Existuje ako identifikačné centrum s perifériou, v ktorej sa súdružnost̉ identity znižuje s odstupom od stredu. Etnicita je spoločnou vierou, subjektívnou schématizáciou a konceptom, ktorý sa realizuje najmä v komunikačných a interakčných procesoch jednotlivcov, menej v materiálnej kultúre (Brather 2000; Korte/Schäfers 1998). Napriek tomu existuje mnoho možností s istou dávkou pravdepodobnosti už v protohistorickom ${ }^{11}$ období, najmä v prípadoch istých jedinečných alebo, naopak, viacnásobne sa opakujúcich, typických, vel’mi príbuzných nálezových situácií, štruktúr či kombinácií artefaktov pokúšat sa v rovine hypotetickej etnické interpretácie prezentovat'.

Čo sa týka konkrétne keltskej etnicity ${ }^{12}$ možno súhlasił s poprednými bádatel’mi v oblasti keltských štúdií, ako P. Sims-Williams (1998; 2006; 2012a; 2012b), A. Falileyev (2009; 2013; 2014), J. T. Koch či A. Minard (Koch a i. 2007; Koch/Minard 2012; Raybould/Sims-Williams 2007), že smerodajným je výskyt keltských jazykových pamiatok od centrálnej keltskej oblasti až po okrajové oblasti. Keltské toponymá, hydronymá i osobné mená sa v centrálnych zónach vyskytujú vždy v skupinách. Keltské izolované názvy sú známe na okraji známeho keltského sveta alebo i mimo neho (obr. 4). To isté platí pre archeologické nálezy. Niet pochýb o tom, že prítomnost pamiatok laténskej kultúry sa kumuluje v oblastiach s relatívne hustým výskytom keltských názvov a mien, čo zvyšuje kumulatívnu hodnotu dôkazov v prospech keltskej prítomnosti. Určite si však nemôžeme dovolit urobit podobné závery v opačnom zmysle na základe absencie takýchto dôkazov. Nepochybne tiež nemožno každý predmet laténskej kultúry automaticky považovat' za stopu po Keltoch a aj osídlenie nových krajov neznamenalo úplné nahradenie tamojšieho obyvatelstva.

Korelácia medzi jazykovými pozostatkami keltského idiómu a fyzickým odtlačkom jeho použivatelov (najmä na periférii keltského sveta) zostáva predmetom d’alšieho výskumu. Používanie termínu „keltský“ v lingvistických štúdiách je presne a jednoznačne definované a pravdepodobne tak môže byt aj v archeológii, aj ked’ tieto dve definície sa nemusia nevyhnutne zhodovat. Pracovná hypotéza - „kde boli Kelti, tam musia byt' keltské miestne názvy" - sa dá považovat' za racionálnu, ale mala by byt aplikovaná opatrne (Repanšek 2013). Jediní „Kelti“, resp. skupiny osídlenia, oblasti, ktoré je možné spolahlivo považovat za keltské, sú tie, ktorých jazykové priradenie robí keltskými. Najdôveryhodnejším dôkazom pre alebo proti kelticite konkrétneho územia bude preto okrem keltských toponým a hydroným prítomnost’ d’alších pozostatkov „starokeltského jazykového fondu - ako sú osobné mená, etnické kmeňové mená a prípadne iné texty" v regióne či vo vel'kých sídelných oblastiach, ktoré sú predmetom výskumu a interpretácie. V kombinácii s vyššie uvedeným vzrastie v budúcnosti pravdepodobne (na úkor klasických antropologických výskumov genetických populácií) tiež dôležitost’ výskumov mitochondriálnej DNA, chromozómu Y, štúdium rozšírenia jednotlivých mutácí špecifických génov a molekulárnych biologických údajov potenciálnych keltských populácií z laténskych pohrebísk $\mathrm{v}$ dostatočne reprezentatívnom množstve, s podporou sprievodných interdisciplinárnych výskumov biochémie, geochémie a molekulárnej medicíny.

\section{LITERATÚRA}

Birkhan 1997

Birkhan 2009

Brather 2000

Collis 1997

Collis 2003

Čižmářová 2004

Davidovic 2008

Drda/Rybová 1998
H. Birkhan: Kelten. Versuch einer Gesamtdarstellung ihrer Kultur. Wien 1997.

H. Birkhan: Nachantike Keltenrezeption. Projektionen keltischer Kultur. Wien 2009.

S. Brather: Ethnische Identitäten als Konstrukte der frühgeschichtlichen Archäologie. Germania 78, 2000, 139-177.

J. Collis: Celtic myths. Antiquity 71, 1997, 195-201.

J. Collis: The Celts: origins, myths \& inventions. Stroud 2003.

J. Čižmářová: Encyklopedie Keltů na Moravě a ve Slezsku. Praha 2004.

A. Davidovic: Kulturanthropologische und archäologische Kulturkonzepte Ein Vergleich. In: Zur Aktualität der Ethnischen Deutung in der Archäologie. 116 Präsentation der Ergebnisse. Projekttutorium WS 2007/08-SS 2008. Berlin 2008, 13, 14. https://www.hu-berlin.de/de/studium/reform/projekttutorien/aktualitaet [18. 02. 2018].

P. Drda/A. Rybová: Keltové a Čechy. Praha 1998.

\footnotetext{
11 Neskôr, resp. v oblastiach dokumentovaných písomnými prameňmi, možno etnicitu nositelov archeologických prameňov hypoteticky interpretovat častejšie a istejšie.

12 Ale platí to zaiste do značnej miery aj pre iné skupiny neskoroantických a včasnostredovekých kmeňov-etník.
} 
Falileyev 2009

Falileyev 2013

Falileyev 2014

Filip 1995

Fried 1975

Goudineau/Guichard/Kaenel 2010

Jones 2003

King 1999

Koch a i. 2007

Koch/Minard 2012

Kokaisl a i. 2016

Korte/Schäfers 1998

Lehman 1992

Maier 2000

Maier 2015

Müller 2009

Pieta 2008

Pohl 1991

Raybould/Sims-Williams 2007

Repanšek 2013

Salač 2011

Schreiber 2008

Sims-Williams 1998

Sims-Williams 2006

Sims-Williams 2012a

Sims-Williams $2012 b$

Sommer 2003

Stifter 2008

Strobel 2006

Strobel 2009
A. I. Falileyev: A Celtic Dacia: Personal Names, Place-Names and Ethnic Names of Celtic Origin in Dacia and Scythia Minor. Aberystwyth 2009.

A. I. Falileyev: The Celtic Balkans. Aberystwyth 2013.

A. I. Falileyev: In search of the Eastern Celts. Studies in geographical names, their distribution and morphology. Budapest 2014.

J. Filip: Keltská civilizace a její dědictví. Praha 1995.

M. Fried: The Notion of Tribe. Menlo Park 1975.

Ch. Goudineau/V. Guichard/G. Kaenel (dir.): Celtes et Gaulois, l'Archéologie face à l'Histoire. Colloque de synthe`se. Glux-en-Glenne 2010.

S. Jones: The Archaeology of Ethnicity. Constructing identities in the past and present. London 2003.

J. King: Kingdoms of the Celts. A History and Guide. Blandford 1999.

J. T. Koch/R. Karl/A. Minard/S. Ó Faoláin: An atlas for Celtic studies: archaeology and names in ancient Europe and early medieval Ireland, Britain and Brittany. Oxford 2007.

J. T. Koch/A. Minard: The Celts History, Life, and Culture. Santa Barbara 2012.

P. Kokaisl/A. Štolfová/P. Fajfrlíková/I. Cejpová/J. Zychová a kol.: Po stopách keltojazyčných obyvatel Evropy: Irsko, Skotsko, Wales, Cornwall, ostrov Man a Bretaň. Praha 2016.

H. Korte/B. Schäfers (Hrsg.): Einführung in Hauptbegriffe der Soziologie. Opladen 1998.

W. P. Lehmann: Historical Linguistics. London - New York 1992.

B. Maier: Die Kelten. München 2000.

B. Maier: Die Kelten Geschichte, Kultur und Sprache. Tübingen 2015.

J. Müller: Materielle Kultur, Territorialität und Bedeutungsinhalte von Identitäten: die Wirkung verdichteter Kommunikationsräume. In: D. Krausse/O. Nakoinz (Hrsg.): Kulturraum und Territorialität. Archäologische Theorien. Rahden 2009, 95-106.

K. Pieta: Keltské osídlenie Slovenska. Mladšia doba laténska. Nitra 2008.

W. Pohl: Conceptions of ethnicity in Early Medieval studies. Archaeologia Polona 29,1991, 39-49.

M. Raybould/P. Sims-Williams: A Corpus of Latin Inscriptions of the Roman Empire containing Celtic personal names. Aberystwyth 2007.

L. Repanšek: Alexander Falileyev: The Celtic Balkans. Aberystwyth. Recenzia. In: A. Gruntar Jermol (ed.): (ZWISCHEN) Sprache und Recht = (Entre) la langue et le droit. Linguistica. Open Journal Systems 53/2, 2013, 273-278.

V. Salač (recenzia): H. Birkhan: Nachantike Keltenrezeption. Projektionen keltischer Kultur. Archeologické rozhledy 63, 2011, 164-169.

S. Schreiber: Ergebnisse, Probleme und Ausblicke. In: Zur Aktualität der Ethnischen Deutung in der Archäologie. Präsentation der Ergebnisse. Projekttutorium WS 2007/08-SS 2008. https://www.hu-berlin.de/de/studium/reform/projekttutorien, aktualitae [18. 02. 2018].

P. Sims-Williams: Celtomania and Celtoscepticism. Cambrian Medieval Celtic Studies 36, 1998, 1-36.

P. Sims-Williams: Ancient Celtic Place-Names in Europe and Asia Minor. Oxford 2006.

P. Sims-Williams: Bronze- and Iron-Age Celtic-speakers: what don't we know, what can't we know, and what could we know? Language, genetics and archaeology 1998-2008. Antiquaries Journal 92, 2012, 427-449.

P. Sims-Williams: Celtic Civilization: Continuity or Coincidence? Cambrian Medieval Celtic Studies 64, 2012, 1-45.

U. Sommer: Materielle Kultur und Ethnizität - eine sinnlose Fragestellung? In: U. Veit/T. L. Kienlin/Ch. Kümmel/S. Schmidt (Hrsg.): Spuren und Botschaften. Interpretationen materieller Kultur. Tübinger Archäologische Taschenbücher 4. Münster - New York - München - Berlin 2003, 205-223.

D. Stifter: Old Celtic Languages. https://www.univie.ac.at/indogermanistik download/Stifter/oldcelt2008 1 general.pdf][28. 02. 2018]; https://rootsofeurope. ku.dk/kalender/arkiv_2012/celtic_spring/Altkeltisch_-_Allgemeines_WS_2010. pdf[27. 11. 2019].

K. Strobel: Galatien, die Galater und Poleis der Galater. Historische Identität und ethnische Tradition. Eirene 42, 2006, 89-123.

K. Strobel: The Galatians in the Roman Empire. Historical tradition and ethnic identity in Hellenistic and Roman Asia Minor. In: T. Derks/N. Roymans (ed.): 
Trefný 2007

Vlčková 2002

Waldhauser 2006

Waldhauser 2012

Wenskus 1961

Zimmer 2017
Ethnic Constructs in Antiquity. The role of $p$ ower and tradition. Amsterdam 2009, 117-144.

M. Trefný: Keltské kmeny v Malé Asii. Disertační práce (Filozofická fakulta, Univerzita Karlova). Praha 2007. Nepublikované

J. Vlčková: Encyklopedie keltské mytologie. Praha 2002.

J. Waldhauser: Encyklopedie Keltů v Čechách. Praha 2006.

J. Waldhauser: Keltské Čechy. Praha 2012.

R. Wenskus: Stammesbildung und Verfassung. Cologne - Graz 1961.

S. Zimmer: Keltové. Mýtus a realita. Praha 2017.

\title{
Internetové zdroje
}

http://wwww.ceskatelevize.cz/ct24/archiv/1132884-keltove [05. 03. 2018].

https://sk.wikipedia.org/wiki/Jazykov\%C3\%A1_rodina [01. 03. 2018].

\section{Die Kelten - das klassische und moderne Paradigma}

\author{
Peter Šalkovský
}

Zusammenfassung

Der Beitrag behandelt klassisches und modernes Paradigma in der Erforschung einer großen Gruppe der Stämme, die die antiken Autoren mit dem Namen Keltoi, Celtae, Galoi benannt haben und die auf großem Teil des mittleren, westlichen und südlichen Europas und in Kleinasien im 6. Jh. vor Chr. bis in das 2. Jh. nach Chr. gelebt hatten, bzw. in einem Teil Frankreichs und auf den Britischen Inseln tief ins Mittelalter und in Fragmenten bis zum heutigen Tag lebende (Abb. 1).

Von den traditionellen Interpretationen als eines großen Ethnikons (bzw. einer großen Gruppe von sprachlich und kulturell verwandten keltischen Stämme), vor allem im Teil der Laienöffentlichkeit bis in die Keltenmanie überwachsend, verschiebt sich die wissenschaftliche Forschung in den letzten Jahrzehnten, vor allem die archäologische, zu dem sog. Keltenskeptizismus, also zu den Zweifeln über der keltischen Ethnizität bis zu ihrer Ableugnung und auch zur Skepsis ihrer automatischen Verbindung mit der archäologischen Latène-Kultur. Skeptisch wird hineingeblickt oder sogar vollständig abgelassen von Versuchen die Verschiebungen und die historischen Schicksale einzelner keltischen Stämme (außer Ausnahmen, die durch die zeitgenössischen schriftlichen Quellen belegt wurden) zu interpretieren.

Dies hängt mit der Verschiebung der Erkenntnis in der Archäologie zusammen - und das in dem Sinne, dass sich die archäologischen Kulturen nicht decken, bzw. dass sie mit den einzelnen Ethnika nicht genau korrespondieren. Und auch deshalb, dass jede konkrete archäologische Kultur (ihre Definition) ein Konstrukt zum Zweck der archäologischen Klassifikation und Rekonstruktion geschaffen ist und den man mit anderen linguistischen oder ethnischen Klassifikationseinheiten nicht identifizieren kann (Collis 1997, 173; 2003).

Die modernen archäologischen, ethnologischen und kulturell-anthropologischen Untersuchungen haben bewiesen, dass die ethnischen Gruppen waren und auch dynamisch sind und sich wie in der Zeit so auch im Raum ändern. Unbeständig waren auch die Grenzen zwischen einzelnen ethnischen Gruppen sowie die Stufe der Intensität der Wahrnehmung der eigenen ethnischen Identität (Jones 2003).

Trotzdem wissen wir, dass sich die keltischen Stämme ihrer verwandten Identität bewusst waren. Darüber zeugt die Tatsache, dass alle mit gegenseitig verständlichen Dialekten gesprochen haben, bzw. mit Sprachen, die aus einer gemeinsamen Protosprache hinausgingen und dieselbe, bzw. sehr nahe Mythologie teilten. Aus ihr gingen auch die altertümlichen keltischen literarischen Denkmäler hervor (Vlčková 2002).

Wir können jedoch voraussetzen, dass keine ursprüngliche und durch die Entwicklung stufenweise entwickelte „große einheitliche keltische Ethnizität" existiert hatte, ähnlich so auch die germanische, baltische, türkische oder slawische, auch wenn ohne Zweifel alle diesen großen ethnischen und Sprachgruppen im Global einen verwandten Ursprung und Ursprache gehabt hatten. Sie waren basale sprach-kulturelle Zweige einer großen urindoeuropäischen Sprachfamilie (Abb. 2).

Die ältesten Belege der keltischen Sprache, datiert in das 6. Jh. vor Chr., kennen wir aus dem Gebiet der Kultur Golasecca, und das aus dem benannten lepontischen Zweig (Maier 2015; Stifter 2008). Weitere größere Konzentrationen von frühen Inschriften in einer der keltischen Sprachen verzeichnen wir auf dem gallisch-hellenischen Gebiet in der Umgebung von Marseille, bei den Keltiberern auf der Pyrenäenhalbinsel (Abb. 2), in Dakien und in Klein-Skythien, 
später auch auf den Britischen Inseln und meistens jüngere Aufschriften auf den Münzen in verschiedenen Teilen der keltischen Welt einschließlich des Gebietes der Slowakei.

Die keltischen Sprachen sind relativ gut erkundet. Die historische Linguistik hat völlig unabhängig von archäologischen Beweisen mit rein formalen Mitteln die enge Verwandtschaft der Sprachen, wie der altertümlichen festländischen so auch der mittelalterlichen Insel-Kelten, nachgewiesen (Abb. 3).

Bei einer weiteren Untersuchung der ethnischen Identität der protohistorischen und mittelalterlichen Gemeinschaften, d. h. dem was man als keltisch, illyrisch, skythisch, aber auch germanisch, langobardisch, hunnisch oder slawisch und so weiter nennen kann, so ist es notwendig zu versuchen den Gegenstand, die Erscheinung, die Struktur historisch, sprachlich oder archäologisch zu definieren. Diese individuellen Definitionen können nicht identifiziert, sondern nur verglichen werden. Offenbar muss man mehr kritisch bei den Konnotationen der ethnischen Einheit in der Beziehung zu beliebig großen sozialen Gruppen oder Identitäten sein, nicht nur zu den Kelten. Obwohl gewisse Vereinfachungen und Generalisationen immer notwendig sind.

Was konkret die keltische Ethnizität betrifft, man kann mit den vorrangigen Forschern im Gebiet der keltischen Studien einverstanden werden (Falileyev 2009; 2013; 2014; Koch/Minard 2012; Raybould/Sims-Williams 2007; Sims-Williams 1998; 2006; 2012a; 2012b), dass maßgebend das Vorkommen der keltischen Sprachdenkmälern ab dem zentralen keltischen Gebiet bis zu den Randgebieten ist. Die keltischen Toponymika, Hydronymien und die Personennamen kommen in den zentralen Zonen immer in Gruppen vor. Die keltischen isolierten Benennungen sind am Rand der bekannten keltischen Welt oder auch außerhalb ihr bekannt (Abb. 4). Dasselbe gilt auch für die archäologischen Funde. Es gibt keine Zweifel darüber, dass die Anwesenheit der Denkmäler der latènezeitlichen Kultur sich in Gebieten mit relativ dichtem Vorkommen der keltischen Benennungen und der Namen, was den kumulativen Wert der Beweise zu Gunsten der keltischen Anwesenheit erhöht, kumuliert. Jedoch können wir uns nicht erlauben ähnliche Schlussfolgerungen im umgekehrten Sinne auf Grund der Abwesenheit solcher Beweise zu machen. Die Korrelation zwischen den sprachlichen Überresten des keltischen Idioms und einem physischen Abdruck seiner Verwender (vor allem auf der Peripherie der keltischen Welt) bleibt somit Gegenstand einer weiteren Forschung.

Die Ausgangspunkte für das weitere Progress in der Erforschung der Kelten gewährt die Kombination der Resultate von weiteren wissenschaftlichen Disziplinen, vor allem der Linguistik, der Geschichte, der Archäologie, der Genetik und teilweise auch der Biochemie, der Geochemie und der Molekularmedizin.

Abb. 1. a - Urheimat der Kelten; b - Verbreitung der Kelten im 5.-1. Jh. vor u. Z. nach traditionellen Interpretationen; cVerbreitung keltischer Flachgräberfelder in Mitteleuropa (bedeutendste Makroregionen mit geschätzter Anzahl von Gräberfeldern); d - schematische Markierung von Gebieten mit Vorkommen ältester frühkeltischer Innschriften (nach Birkhan 1997, Abb. 322, ergänzt; Filip 1995, Abb. 19). Kartenvorlage: https://commons.wikimedia. org/wiki/File:Celts.svg [01. 03. 2018].

Abb. 2. Keltische Sprachen im Rahmen des Stammbaums inerhlb des indoeuropäischen Sprachraums (Lehman 1992, 120; Stifter 2008, Abb. III. 1. 1, ergänzt).

Abb. 3. Genealogie keltischer Sprachen (Stifter 2008, Abb. III. 1. 4, ergänzt).

Abb. 4. Schematisierte Darstellung der Intensität des Vorkommens keltischer Namen in den lateinischen Innschriften im Römischen Reich. Legende: a - Verbreitung keltischer Stämme; b - schwächeres Vorkommen (cca 0,1-2,9 \%); c - mittelstarkes Vorkommen (cca 3-3,9 \%); d - stärkeres Vorkommen (cca 4-6 \%; nach Raybould/Sims-Williams 2007, ergänzt).

Translated by Viera Tejbusová

Zusammenfassung übersetzt von Lubomír Novotný Abbildungstexte übersetzt von Susanne Stegmann-Rajtár

PhDr. Peter Šalkovský, DrSc.

Archeologický ústav SAV

Akademická 2

SK - 94921 Nitra

petersalkovsky@savba.sk 
